\title{
KUALITAS PELAYANAN PASIEN B.P.J.S. DI RUMAH SAKIT
}

\author{
Raina Dwi Miswara \\ Ikatan Sarjana Wanita Indonesia (ISWI) DIY; rainadwi65@gmail.com \\ Samodra Wibawa \\ Jurusan Adm. Negara, Fisipol UNTIDAR; samodra03@yahoo.com
}

\begin{abstract}
Public services have become an important issue in Indonesia for more than a decade. One of them is health services, which is one of the basic needs whose provision must be held by the government as mandated in Article $28 \mathrm{H}$ of the Constitution. For this reason, the Social Insurance Administration Organization (Badan Penyelenggara Jaminan Sosial, BPJS) was established on 1 January 2014. Are services to patients covered by BPJS satisfiying enough? This paper answers this question through literature studies and observations, comparing four hospitals in Java and two outside Java. It was found that there were still many problems in this service, and the most prominent was the queuing system that was unsatisfactory and too few staff and medical personnel and rooms compared to the increasing number of BPJS patients. In order to maintain public trust, the government needs to resolve this problem immediately.
\end{abstract}

Key words: BPJS, health service quality, hospitals, queues system, treatment room

Abstrak: Pelayanan publik di Indonesia sejak lebih dari satu dasawarsa terakhir telah menjadi isu penting di tengah masyarakat. Salah satunya adalah pelayanan kesehatan, yang merupakan salah satu kebutuhan dasar masyarakat yang penyediaannya wajib diselenggarakan oleh pemerintah sebagaimana telah diamanatkan dalam Undang-undang Dasar 1945 pasal 28 H. Untuk itu telah dibentuk Badan Penyelenggara Jaminan Sosial (BPJS) Kesehatan pada 1 Januari 2014. Apakah pelayanan terhadap pasien yang ditanggung oleh BPJS sudah memuaskan?Makalah ini menjawab pertanyaan tersebut melalui studi literatur dan observasi dengan membandingkan empat rumah sakit di Jawa dan dua di luar Jawa.Ditemukan masih ada banyak masalah dalam pelayanan ini, dan yang paling menonjol adalah sitem antrian yang tidak memuaskan dan terlalu sedikitnya jumlah pegawai dan tenaga medis serta ruang rawat inap dibandingkan jumlah pasien BPJS yang terus meningkat.Pemerintah perlu segera menyelesaikan masalah ini, jika tidak ingin kehilangan kepercayaan masyarakat terhadapnya.

Kata kunci: BPJS, kualitas pelayanan kesehatan, rumah sakit, antrian, rawat inap

\section{Pendahuluan}

Salah satu tujuan negara yang tertulis dalam Pembukaan UUD adalah meningkatkan kesejahteraan rakyat. Untuk itu dalam perubahan ke-empat UUD (2002) dikatakan, bahwa setiap warga negara berhak memperoleh jaminan sosial yang memungkinkannya untuk hidup secara layak sebagai manusia (pasal 28H dan 34). Ini mempertegas Tap MPR No. X/MPR/2001 yang menugasi presiden untuk membentuk sistem jaminan sosial nasional yang memberikan perlindungan sosial bagi masyarakat 
secara menyeluruh dan terpadu. Berdasarkan ini dibuatlah UU No. 40/2004 tentang Sistem Jaminan Sosial Nasional. Namun Badan Penyelenggara Jaminan Sosial (BPJS) Kesehatan baru terbentuk sepuluh tahun kemudian (2014), yang merupakan suatu badan hukum publik yang bekerja berdasarkan prinsip gotong-royong, nirlaba, keterbukaan, akuntabilitas yang hasilnya dipergunakan seluruhnya untuk kepentingan peserta. Sebelum tahun ini, yakni sejak 2005, penjaminan kesehatan dilakukan oleh PT Askes, namun khusus untuk warga miskin. PT Askes inilah yang kemudian berubah menjadi BPJS.

Pelayanan kesehatan merupakan salah satu bentuk pelayanan publik. Untuk itu harus patuh pada UU No. 25/2009 ttg Pelayanan Publik. Disebutkan dalam UU ini, bahwa suatu pelayanan haruslah sekurang-kurangnya memenuhi komponen: dasar hukum, persyaratan, sistem, mekanisme atau prosedur, biaya, produk pelayanan, sarana, prasarana, kompetensi pelaksana, pengawasan internal, penanganan pengaduan, masukan dan saran, jumlah pelaksana, jaminan pelayanan yang memberikan kepastian pelayanan, jaminan keamanan dan keselamatan pelayanan, bebas dari bahaya dan resiko keragu-raguan serta evaluasi kinerja pelaksana (https//id.m.wikipedia.org).

BPJS harus menyusun dan menetapkan maklumat pelayanan yang merupakan pernyataan kesanggupan melaksanakan pelayanan sesuai dengan standar dan wajib mempublikasikannya secara jelas dan luas. BPJS harus selalu meningkatkan kualitas pelayanan. Semua program yang disusun harus berpihak pada rakyat dan mempermudah dalam mendapatkan pelayanan kesehatan.

Berdasarkan latar belakang di atas, makalah mengajukan pertanyaan sbb.:

a. Bagaimana kualitas pelayanan pasien BPJS di rumah sakit di Jawa dan di Luar Jawa?

b. Masalah apa yang ditemui dan bagaimana solusinya terhadap pelaksanaan pelayanan tersebut?

\section{Metode}

Makalah ini ditulis berdasarkan studi pustaka dan sedikit observasi. Studi pustaka dilakukan terhadap kasus-kasus di beberapa rumah sakit yang telah dikaji oleh penulis lain, baik dalam bentuk tugas akhir studi maupun artikel, sedangkan observasi dilakukan di RS Sarjito Jogja. Rumah sakit yang dikaji di sini berjumlah enam buah, di mana empat di Jawa dan dua di luar Jawa. Pemilihan rumah sakit dilakukan tidak secara sistematis, melainkan secara kebetulan berdasarkan ketersediaan/kemudahan diperolehnya literatur.

\section{Kualitas Pelayanan}

Bagi perusahaan swasta kualitas dipandang sebagai strategi dasar bisnis yang menghasilkan barang dan jasa yang memenuhi kebutuhan dan kepuasan konsumen internal dan eksternal, secara eksplisit dan implisit.Untuk ini dikerahkan seluruh kemampuan sumber daya manajemen, modal, teknologi, peralatan, material, sistem dan manusia untuk menghasilkan barang atau jasa bernilai tambah bagi masyarakat serta 
memberikan keuntungan kepada para pemegang saham. ${ }^{1}$

Feigenbaum memandang kualitas sepenuhnya sebagai kepuasan pelanggan (full costumer satisfaction). Suatu produkberkualitas apabila dapat memberikan kepuasan-penuh kepada konsumen. ${ }^{2}$ Garvin dan Davis memahami kualitas sebagai kondisi dinamis dari suatu produk, manusia/tenaga kerja, prosesdan tugas serta lingkungan yang memenuhi atau melebihi harapan pelangganatau konsumen. ${ }^{3}$

Secara umum pengertian pelayanan adalah kegiatan atautindakan yang berkaitan dengan pemenuhan kebutuhan kepada orang lain atau pelanggan. Menurut Gronroos, pelayanan merupakan bagian dari jasa seseorang kepadaorang lain baik yang dapat dilihat (eksplisit service) maupun yang tidak dapatdilihat, yang hanya bisa dirasakan (implisit service) sampai pada fasilitas fasilitas pendukung yang harus tersedia dalam penjualan jasa dan benda-benda lainnya. ${ }^{4}$

Sementara itu pengertian jasa menurut Kotler adalah setiap tindakan atau perbuatan yang dapat ditawarkan olch suatu pihak kepada pihak lain, yang pada dasarnya intangible (tidak berwujud fisik) dan tidak mengakibatkan

1 Ibrahim, B., 1997, TQM, Panduan Untuk Menghadapi Pasar Global, Djambatan, Jakarta, hlm. 54.

2 Nasution, Nur, 2004, Manajemen Jasa Terpadu (Total Service Management), Ghalia Indnesia, Bogor, hlm. 41.

IIbid.

${ }^{4}$ Jasfar, Farid, 2005, Manajemen Jasa Pendekatan Terpadu. Penerbit: Gahlia Indonesia. Bogor, hlm. 15. kepemilikan apapun, produksi jasa yang berkaitan dengan produk fisik atau tidak. ${ }^{5}$

Dari pengertian pelayanan dan jasa tersebut diatas maka pelayanan diartikan sebagai bagian dari jasa yang artinya hampir sama. Kualitas jasasifatnya tidak nyatasehingga kualitas pelayanan adalah bagaimana tanggapan pelangggan terhadap jasa yang dikonsumsi atau dirasakannya. ${ }^{6}$

Beberapa pendapat tentang pengertian kualitas pelayanan antara lain dikemukakan oleh Zeithamal dan Bitner (dalam Arif, 2007) adalah kualitas jasa atau pelayanan merupakan penyampaian jasa yang baik atau sangat baik, jika dibanding dengan ekspektasi pelanggan.7Sementara itu pengertian kualitas pelayanan yang disampaikan oleh Wyckof adalah kualitas pelayanan sebagai tingkat kesempurnaan yang diharapkan dan pengendalian akan kesempurnaan tersebut untuk memenuhi keinginan pelanggan. Sedangkan menurut Parasuraman, kualitas pelayanan merupakan perbandingan antara layanan yang dirasakan sama atau melebihi kualitas layanan yang diharapkan, maka layanan dapat dikatakan berkualitas dan memuskan. ${ }^{8}$

Meskipun definisi kualitas pelayanan diartikan banyak makna namun pada prinsipnya pelayanan berkualitasadalah menjaga kepuasan pelanggan untuk menggunakan jasa pelayanan secara berkesinambungan dengan cara menepati semua janji kepada

\footnotetext{
${ }^{5}$ Nasution, Nur, Op.Cit., hlm. 6.

${ }^{6}$ Jasfar, Farid, Op.Cit., hlm. 47.

${ }^{7}$ Arief, 2007, Pemasaran Jasa Dan Kualitas Pelayanan, Bayu Media Publishing, Malang, hlm. 120.

8Ibid., hlm. 118.
} 
pelanggan termasuk diantaranya ketepatan waktu, bebas cacat atau cela dan kesesuaian dengan persyaratan.

Pelayanan kesehatan masyarakat merupakan salah satu bagian dari pelayanan publik.Untuk mengetahui pengertian pelayanan kesehatan masyarakat maka perlu mengetahui terlebih dahulu tentang definisi publik. Inu Kencana (dalam Sinambela, 2006) mendefinisikan publik adalah sejumlah manusia yang memiliki kebersamaan berpikir, perasaan, harapan, dan tindakan yang benar dan baik berdasarkan nilainilai norma yang mereka memiliki. Oleh karena itu pelayanan publik diartikan sebagai setiap kegiatan yang dilakukan oleh pemerintah terhadap masyarakat yang memiliki kegiatan yang menguntungkan dalam suatu kumpulan atau kesatuan, dan menawarkan kepuasan meskipun hasilnya tidak terikat pada suatu produk secara fisik. ${ }^{9}$

\section{Pelayanan Publik dalam Peraturan Perundang-undangan}

Pengertian pelayanan publik menurut pasal 1 ayat 1 UU No. 25/2009 adalah kegiatan atau rangkaian kegiatan dalam rangka pemenuhan kebutuhan pelayanan sesuai dengan peraturan perundang-undangan bagi setiap warga negara dan penduduk atas barang, jasa dan/atau pelayanan administrasi yang disediakan oleh penyelenggara pelayanan publik.

Dalam KEPMENPAN No. 63/KEPMEN/PAN/17/2003 dirumuskan bahwa pelayanan publik adalah segala

9 Sinambela, Lijan Poltak, 2006, Reformasi Pelayanan Publik, Teori, Kebijakan dan Implementasi, Bumi Aksara, Bandung, hlm 5 . kegiatan pelayanan yang dilaksanakan oleh penyelenggara pelayanan publik sebagai upaya pemenuhan kebutuhan dasar sesuai dengan hak-hak sipil setiap warga negara dan penduduk atas suatu barang, jasa dan atau pelayanan administrasi yang disediakan oleh penyelenggara pelayanan publik.

Mengingat fungsi utama dari pemerintah adalah melayani rakyat, maka setiap instansi pemerintahan adalah memberikan pelayanan atau menyelenggarakan pelayanan publik (public service) dan kesejahteraan bagi rakyatnya (public welfare) berdasarkan peraturan perundang-undangan. ${ }^{10}$

Untuk melaksanakan ketentuan peraturan perundang-undangan tersebut di atas, pemerintah baik pusat maupun daerah bertanggung jawab dalam melaksanakan pelayanan publik dalam segala bentuk barang publik maupun jasa publik untuk memenuhi kebutuhan masyarakat.

\section{Pelayanan Kesehatan terhadap Pasien BPJS di Rumah Sakit}

Bagaimana pelayanan kesehatan program BPJS yang telah dilaksanakan oleh Pemerintah, berikut ini disajikan kinerja dari empat rumah sakit di Jawa dan dua di luar Jawa.

a.RSUD Pandan Arang Kabupaten
Boyolali ${ }^{11}$

10 Busrizalti, M., 2013, Hukum Pemda: Otonomi Daerah dan Implikasinya, Cet. I, Total Media, Yogyakarta, hlm. 140.

11 Prasetyo, Yudi dan Eny Kusdarini, 2016, "Implementasi Program Badan Penyelenggara Jaminan Sosial Kesehatan Di Rumah Sakit Umum Daerah Pandan Arang Kabupaten Boyolali", Jurnal Pendidikan Kewarganegaraan dan Hukum 2016. 
Kebijakan BPJS di RSUD Pandan Arang Kabupaten Boyolali telah dilaksanakan dengan relatif baik, meskipun terlihat masih banyak warga masyarakat yang kurang memahami bagaimana tatacara mendapatkan dan menggunakan fasilitas BPJS. Hal tersebut disebabkan karena sosialisai program BPJS kesehatan kepada masyarakat belum optimal, sumber daya manusia yang masih kurang terlatih, jumlah tenaga pelayanan yang belum mencukupi untuk melayani pasien yang begitu banyak, rumitnya birokrasi, komunikasi yang kurang lancar, rendahnya kesadaran masyarakat dalam keikutsertakan program BPJS dan perbedaan pemahaman antara BPJS dengan RSUD Pandan Arang mengenai besarnya standar tarif pembayaran.

b. Instalasi Tulip RSUP Sarjito Yogyakart Instalasi Tulip RSUP Sarjito adalah instalasi khusus untuk menangani semua pasien kanker dan sejenisnya. Penulis mengamati secara langsung pelaksanaan pelayanan kesehatan di Instalasi Tulip tersebut dengan menitik beratkan pada kepuasan pasien dalam menerima pelayanan kesehatan. Sebagai RS tipe A sudah pasti menjadi rujukan dari semua rumah sakit daerah tipe di bawahnya. Secara umum pelaksanaan BPJS kesehatan di Instalasi Tulip RSUP Sarjito Yogyakarta dapat dikatakan baik, namun belum sepenuhnya pasien merasakan kepuasaan dalam proses pelayanan.

Pasien kanker yang ditangani di Instalasi Tulip RSUP Dr. Sardjito Yogyakarta merupakan pasien rujukan dari RSUD dari berbagai daerah di Jateng dan Jatim.Setiap hari lebih dari seratus pasien kanker yang harus ditangani di Instalasi Tulip tersebut. RSUP Sarjito telah melaksanakan kewajiban sebagai mitra BPJS yang dapat dilihat dari cara pembayaran pasien peserta BPJS berdasarkan pada diagnosa-diagnosa atau kasus-kasus yang relatif sama. Surat Eligibilitas Pasien (SEP) yang diterima pasien sebagai bukti penjaminan harus disertakan dalam pengambilan obat, cek darah, dll.yang akan digunakan dasar Rumah Sakit untuk "klaim" ke BPJS. Kalau dilihat dari besarnya biaya perawatan kesehatan yang diganti oleh BPJS, maka hampir semua pasien terutama bagi pasien yang tidak mampu merasakan kepuasan dan kepercayaannya terhadap program BPJS.

Beberapa komponen standar pelayanan yang disediakan oleh Instalasi Tulip RSUP Dr. Sardjito telah menunjukkan kinerjanya dengan baik dalam melayani pasien peserta, meskipun masih ada beberapa kekurangan. Kecepatan dan kecekatan yang ditunjukkan oleh paramedis perawat, tenaga administrasi, satpam dan tenaga kebersihan telah memberikan pelayanan dengan memuaskan. Tepat waktu dengan tertib dalam melayani pasien.

Ketersedian sarana fotocopy yang kurang memadai dan tempatnya yang jauh menjadi kendala terhambatnya proses pelayanan administrasi. Sementara untuk konsultasi dokter masih memerlukan waktu tunggu yang cukup lama.Selain itu antrian 
panjang untuk mendapatkan obat juga banyak dikeluhkan oleh pasien BPJS.

Pendaftaran pasien secara online yang tujuannya untuk mempercepat proses pada kenyataannya belum bisa mengatasi masalah administrasi. Pasien tetap datang lebih awal untuk mendapatkan nomer antrian dan verifikasi dokumen pendaftaran. Pendaftaran online hanya untuk memastikan bahwa pasien akan ditangani dokter. Itupun kadangkadang beberapa pasien terakhir pada akhirnya ditunda pelayanannya pada esok hari, karena dokter kelelahan memeriksa sekian banyaknya pasien. Urutan penanganan dilakukan berdasarkan nomor antrian manual; dan kalau pas dipanggil tidak di tempat, maka pasien akan dilompati dan harus mengulang dari awal. Hal ini membuat frustrasi pasien tersebut. Pembatasan waktu rawat inap juga menjadikan ketidakpuasan tersendiri pagi pasien BPJS. Namun ini dapat dipahami, karena relatif sedikitnya jumlah kamar dibanding jumlah pasien BPJS yang "membludak". Banyak pasien BPJS yang sebenarnya berhak menempati kamar kelas utama terpaksa tidak bisa dipenuhi.

\section{c. PKU Muhammadiyah Yogyakarta ${ }^{12}$}

Rumah Sakit PKU Muhammadiyah Yogyakarta sebagai mitra dari BPJS Kesehatan telah mematuhi segala persyaratan yang telah ditentukan didalam MoU atau Surat Perjanjian

12 Aprianto, Anggit, 2017, Implementasi Pelayanan Kesehatan Terhadap Peserta Bpjs Kesehatan Di RS PKU Muhammadiyah Yogyakarta, Skripsi, Fakultas Hukum, Universitas Muhammadiyah Yogyakarta.
Kerja Sama (SPK).Pelaksanaan jaminan sosial terhadap pelayanan bagi pasien BPJS kesehatan di RS PKU Muhammadiyah Yogyakarta sudah terlihat berjalan dengan baik, meskipun masih perlu ditingkatkan pelayanannya. Keikutsertaan PKU Muhammadiyah Yogyakarta dalam mengikuti INA-CBGs (Indonesia Case Base Group ) menunjukkan bahwa PKU Muhammadiyah Yogyakarta dalam pelayanan kesehatan kepada pasien peserta BPJS Kesehatan telah menggunakan sistem pembayaran paket berdasarkan penyakit yang diderita oleh pasien.

Sementara itu dalam kecepatan proses pelayanan kesehatan dan proses pelayanan administrasi yang masih terdapat beberapa kendala. Sistem rujukan pasien yang diterapkan masih dinilai berjalan lamban, pembayaran klaim peserta BPJS juga masih dianggap membebani pihak pasien dan rumah sakit karena adanya pembatasan waktu rawat inapnya. Tingkat kepuasan pasien peserta BPJS dalam menerima pelayanan dapat menunjukkan indikator bahwa kualitas pelayanan PKU Muhammadiyah sudah baik, walaupun tidak sedikit pasien merasa kurang puas dengan pelayanannya.

Beberapa ketentuan seperti penggunaan obat-obatan yang harus disesuaikan dengan INA-CBGs masih dianggap memberatkan. Demikian juga dengan waktu penerbitan SEP (surat elegalitas pasien) yang lambat dan juga keterlambatan pembayaran klaim. 
d. RSUD Dr. M. Soewandhie Kota Surabaya ${ }^{13}$

Di RSUD Dr. M. Soewandhie Kota Surabaya dapat dilihat, bahwa aspek fisik berupa fasilitas ruang tunggu belum mencukupi, terutama di ruang tunggu poli, pendaftaran dan farmasi.Jumlah tempat duduk dan luas ruang tunggu masih kurang untuk menampung banyaknya pasien peserta BPJS.Selain itu, ketersediaan bed untuk pasien rawat inap juga masih belum mencukupi untuk jumlah pasien yang terus meningkat dari waktu ke waktu.

Secara umum kinerja pelayanannya belum memuaskan, terutama pada ketepatan waktu yang belum sesuai dengan standar waktu yang telah ditetapkan yaitu 60 menit dimulai dari pendaftaran sampai dengan mendapatkan pelayanan di poli.Untuk pelayanan farmasi dinilai juga melebihi waktu yang dijanjikan, yakni untuk obat racikan 60 menit dan obat jadi 30 menit.Sedangkan untuk kecepatan terhadap tanggapan keluhan telah dinilai baik, yaitu tersedia berbagai media untuk menyampaikan keluhan atau masukan.Para petugas medis atau administrasi pada bagian masingmasing selalu siap dalam membantu dan memberi informasi yang dibutuhkan oleh pasien BPJS.

13 Larasati, Nikken, 2016, “Kualitas Pelayanan Program Jaminan Kesehatan Nasional Dalam Rangka Menjamin Perlindungan Kesehatan Bagi Peserta BPJS Di RSUD Dr. M.Soewandhie Kota Surabaya", Jurnal Kebijakan dan Manajemen Publik, Volume 4, Nomor 2, Mei-Agustus 2016.
Untuk tindak lanjut penanganan keluhan dan masukan dinilai masih kurang baik, hal ini ditunjukakn pada data IKM (Indeks Kepuasan Masyarakat) yaitu 35,18 yang artinya kurang baik.

Sistem pelayanan (prosedur dan persyaratan) masih dirasakan menyulitkan pasien BPJS, yaitu antrian yang diterapkan belum efektif dalam menangani banyaknya pasien. Tarif INA CBGs dinilai masih sangat rendah dibanding real cost-nya. Obat yang diberikanpun terbatas pada obat generik saja dan jumlahnya terbatas terutama obat untuk penyakit berat.Akibatnya petugas medis terpaksa memberikan pelayanan perawatan yang paling dibutuhkan saja oleh pasien. Akibat selanjutnya adalah pasien menumpuk di RS tipe A dan $B$, terutama rumah sakit milik pemerintah.

\section{e.RSUD Kabupaten Siak ${ }^{14}$}

Pelayanan kesehatan bagi pasien BPJS di RSUD Kabupaten Siak pada tahun 2016 dapat dikatakan masih rendah, yang ditandai adanya berkas-berkas dokumen tidak tertata dengan rapi, bahkan ada berkas yang hilang sehingga tidak dapat dipertanggungjawabkan kepada pasien. Dalam menetapkan persyaratan administrasipun masih ditemukan adanya diskriminasi dalam pemberian pelayanan.

Namun memang semua urusan kesehatan pasien diselesaikan sampai

14 Novrialdi. J,“Pelayanan Kesehatan Bagi Pasien BPJS (Badan Penyelenggara Jaminan Sosial) Di Rumah Sakit Umum Daerah Kabupaten Siak Tahun 2016", Jurnal JOM FISIP Vol. 4 No. 2 - Oktober 2017. 
tuntas.Tingkat pendidikan sumber daya manusia dan kecepatan dalam menangani pasien juga menjadi pendukung dalam meningkatkan kualitas pelayanan RS tersebut, sementara kreatifitas dan inisiatif para pegawai masih kurang.

\section{f. RSUD Lapangan Sawang Kabupaten} Sitaro ${ }^{15}$

Pelaksanaan Program BPJS Kesehatan di RSUD Lapangan Sawang Kabupaten Sitaro belum dapat di katakan baik karena pelayanannya belum dapat dirasakan sepenuhnya oleh masyarakat yang kurang mampu.Selain masih kurangnya sosialisasi tentang bagaimana caranya mengurus berkas-berkas administrasi peserta BPJS, pelaksanaan pelayanan program BPJS yang kurang baik dikarenakan oleh kurangnya kesadaran dan tanggung jawab para pegawai dalam melaksanakan tugasnya.

\section{Kritik dan Saran}

Dari lima literatur yang direview dan satu pengamatan di atas diperoleh setidaknya lima hal positif yang dijumpai hampir di semua RS, yaitu:

a. Petugas relatif cekatan

b. Sarana relatif memadai

c. Ada tempat keluhan

15 Burung, Faris, Sofia Pangemanan dan Yurnie Sendow, 2017, "Implementasi Pelayanan Kesehatan Masyarakat Melaui Program Bpjs Kesehatan (Suatu Studi di RSUD Lapangan Sawang Kabupaten Sitaro), Jurnal Eksekutif Vol. 1 No. 1 2017, Program Studi Ilmu Pemerintahan FISIP-Unsrat, Manado. d. Urusan ditangani sampai tuntas, meskipun lama.

Sementara itu masalah atau hal yang masih dikeluhkan oleh pasien dapat dirangkum menjadi Tabel 1 . Ternyata masih sangat banyak masalah dalam pelayanan pasien BPJS di RS.Memang tidak semua masalah ditemui di setiap RS.Namun masalah yang tidak muncul di suatu RS dalam tabel di atas tidak berarti bahwa masalah tsb tidak ada di RS tersebut, melainkan bisa juga karena luput dari pengamatan peneliti.Karena itu, daftar di atas kiranya patut menjadi perhatian oleh setiap RS maupun BPJS sendiri dalam meningkatkan kualitas pelayanannya. Masalah yang muncul di dua RS dalam tabel di atas dapat dianggap sebagai masalah penting/pokok, yang bisa jadi dijumpai di semua RS, yaitu:

a. Sebagian warga/pasien belum memahami tata-cara BPJS dengan baik (no. 1)

b. Sistem antrian belum baik (no. 14)

c. Ruang rawat inap relatif sedikit dibanding banyaknya pasien (no. 15)

d. Pembatasan waktu rawat inap (no. 16)

e. Tarif INA CBGs lebihrendah dibanding real cost-nya (no. 18).

Rupanya tetap saja ada anggota masyarakat yang belum memahami dengan baik prosedur pelayanan oleh RS bagi pasien BPJS.Bagi mereka masih diperlukan adanya penyuluhan di rumah mereka sendiri, tapi bisa juga di RS disediakan pegawai yang mendampingi pasien yang masih bingung seperti ini. Sementara tariff INA-CBGs kiranya merupakan persoalan yang harus segera diselesaikan oleh pemerintah. Jika tidak, maka penumpukan pasien di RS tipe A dan B seperti yang terjadi di Sarjito akan 
terus bertambah (Larasati 2016), yang pada akhirnya akan menambah ketidakpuasan pasien.

Persoalan sistem antrian dan keterbatasan ruang inap kiranya merupakan persoalan besar. Harusnya kartu antrian benar-benar dipatuhi.
Pasien boleh meninggalkan lokasi, jika antriannya masih panjang. Jika nomor antriannya dipanggil tapi dia tidak di tempat, maka dia dilewati, dan kemudian tetap memperoleh urutan pertama setelah pasien nomor urut setelahnya ditangani. harus

Tabel 1. Masalah-masalah Pelayanan di Enam Rumah Sakit

\begin{tabular}{|c|c|c|c|c|c|c|c|}
\hline \multirow[t]{2}{*}{ No. } & \multirow[t]{2}{*}{ Masalah } & \multicolumn{6}{|c|}{ Rumah Sakit } \\
\hline & & $\begin{array}{l}\text { RS } \\
\text { Pandan } \\
\text { Arang } \\
\text { Boyolali }\end{array}$ & $\begin{array}{l}\text { RS } \\
\text { Sarjito } \\
\text { Jogja }\end{array}$ & $\begin{array}{l}\text { PKU } \\
\text { Muha } \\
\text { mmad } \\
\text { iyah } \\
\text { Jogja }\end{array}$ & $\begin{array}{l}\text { RS } \\
\text { Soewa } \\
\text { ndhie } \\
\text { Surab } \\
\text { aya }\end{array}$ & $\begin{array}{l}\text { RS } \\
\text { Siak }\end{array}$ & $\begin{array}{l}\text { RS } \\
\text { Sita } \\
\text { ro }\end{array}$ \\
\hline 1. & $\begin{array}{l}\text { Warga masyarakat kurang memahami } \\
\text { tatacara BPJS }\end{array}$ & $\mathrm{v}$ & & & & & $\mathrm{v}$ \\
\hline 2. & Rumitnya birokrasi & $\mathrm{v}$ & & & & & \\
\hline 3. & $\begin{array}{l}\text { Berkas-berkas dokumen tidak tertata } \\
\text { dengan rapi, bahkan ada berkas yang } \\
\text { hilang sehingga tidak dapat } \\
\text { dipertanggungjawabkan kepada } \\
\text { pasien }\end{array}$ & & & & & $\mathrm{v}$ & \\
\hline 4. & $\begin{array}{l}\text { Masih ada diskriminasi dalam } \\
\text { pemberian pelayanan }\end{array}$ & & & & & $\mathrm{v}$ & \\
\hline 5. & $\begin{array}{l}\text { Kreatifitas dan inisiatif pegawai masih } \\
\text { kurang }\end{array}$ & & & & & $\mathrm{v}$ & \\
\hline 6. & $\begin{array}{l}\text { Kurangnya kesadaran dan tanggung } \\
\text { jawab para pegawai dalam } \\
\text { melaksanakan tugasnya }\end{array}$ & & & & & & $\mathrm{v}$ \\
\hline 7. & Sumber daya manusia kurang terlatih & $\mathrm{v}$ & & & & & \\
\hline 8. & $\begin{array}{l}\text { Jumlah tenaga pelayanan belum } \\
\text { mencukupi (atau: pasien } \\
\text { sangat/terlalu banyak) }\end{array}$ & $\mathrm{v}$ & & & & & \\
\hline 9. & $\begin{array}{l}\text { Perbedaan pemahaman antara BPJS } \\
\text { dengan RSUD tentang standar tarif }\end{array}$ & $\mathrm{v}$ & & & & & \\
\hline 10. & Komunikasi kurang lancar & $\mathrm{v}$ & & & & & \\
\hline 11. & Sarana fotocopy belum memadai & & $\mathrm{v}$ & & & & \\
\hline
\end{tabular}




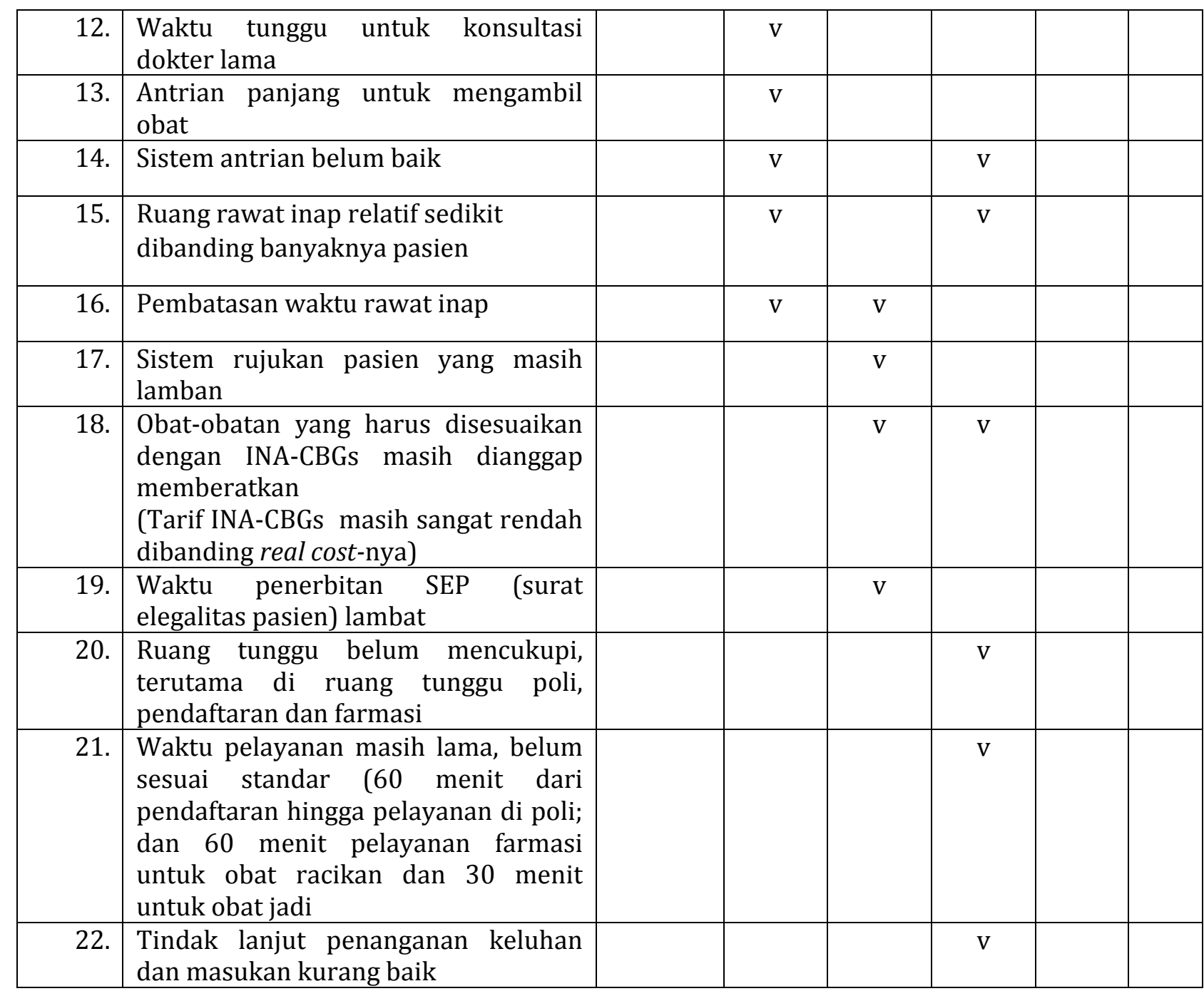

mengulang dari awal, ini sama saja tidak antri. Hal ini sangat menyengsarakan pasien, karena mereka harus menunggu berjam-jam.Mereka tidak berani pergi jauh, karena takut kelewatan ketika sudah saatnya diperiksa; dan jam periksa ini tidak dapat diprediksikan lamanya. Jadi harusnya: mereka yang kelewatan (tidak di tempat ketika dipanggil) tetap dipersilakan masuk ruang pemeriksaan pada giliran pertama berikutnya. Mekanisme ini harus diumumkan di raang tunggu, sehingga semua pasien faham. Daftar nomor urut pasien harus dicetak dan ditempelkan di ruang tunggu tersebut, sehingga tidak ada kecurigaan di antara para pasien terhadap nomor urut pasien lain. (Misalnya bahwa pasien nomor 10 meninggalkan tempat dan baru datang lagi setelah pasien nomor 15 dipanggil. Agar tidak dicurigai bahwa dia memperoleh nomor istimewa oleh pasien lain yang baru melihat dia yang datang terlambat itu, maka daftar nama antrian harus ditempelkan di ruang tunggu.)

Selain saran di atas, dari literatur yang telah direview dapat dirangkum beberapa saran sebagai berikut (sebenarnya daftar masalah di atas sudah implisit menunjukkan, apa tindakan yang perlu segera dilakukan):

a. Bagian keuangan dan penagihan BPJS Kesehatan diharapkan rutin mengingatkan pembayaran iuran 
dengan mengirimkan SMS Gateway dan mengirimkan surat tagihan, serta seluruh Duta BPJS Kesehatan rajin memotivasi peserta perorangan untuk melakukan pembayaran iuran di bank secara teratur.

b. RS harus cepat melakukan tanggapan terhadap masalah pelayanan yang dikeluhkan.

c. Terkait dengan melonjaknya jumlah pasien sejak diterapkannya BPJS, RS perlu menambah jumlah ruang pelayanan dan dokter serta perawat maupun karyawan lain. Bukan hanya jumlah tapi juga kualitas sarpras dan profesionalitas pegawai harus ditingkatkan.

\section{PENUTUP}

Kualitas pelayanan pasien BPJS di rumah sakit di pulau Jawa dan luar pula Jawa pada umumnya sudah cukup baik. Para pasien merasa sangat terbantu secara finansial oleh sistem ini. Tapi beberapa kekurangan masih dirasakan oleh masyarakat, dan beberapa dapat dipahami. Yang paling mencolok adalah, karena menjadi begitu banyaknya pasien yang memenuhi RS, sistem antrian yang tidak baik dan relatif sedikitnya jumlah pegawai dan ruang rawat inap. Ini harus segera ditangani, jika pemerintah ingin memperoleh kepercayaan yang tinggi dari masyarakat.

\section{DAFTAR PUSTAKA}

Aprianto, Anggit, 2017, Implementasi Pelayanan Kesehatan Terhadap Peserta Bpjs Kesehatan Di RS PKU Muhammadiyah Yogyakarta, Skripsi, Fakultas Hukum, Universitas Muhammadiyah Yogyakarta
Arief, 2007, Pemasaran Jasa Dan Kualitas Pelayanan, Bayu Media Publishing, Malang

Burung, Faris, Sofia Pangemanan dan Yurnie Sendow, 2017, "Implementasi Pelayanan Kesehatan Masyarakat Melaui Program Bpjs Kesehatan (Suatu Studi di RSUD Lapangan Sawang Kabupaten Sitaro), Jurnal Eksekutif Vol. 1 No. 1 2017, Program Studi Ilmu Pemerintahan FISIP-Unsrat, Manado

Busrizalti, M., 2013, Hukum Pemda: Otonomi Daerah dan Implikasinya, Cet. I, Total Media, Yogyakarta

Ibrahim, B., 1997, TQM, Panduan Untuk Menghadapi Pasar Global, Djambatan, Jakarta

Jasfar, Farid, 2005, Manajemen Jasa Pendekatan Terpadu. Penerbit: Gahlia Indonesia, Bogor

Larasati, Nikken, 2016, "Kualitas Pelayanan Program Jaminan Kesehatan Nasional Dalam Rangka Menjamin Perlindungan Kesehatan Bagi Peserta BPJS Di RSUD Dr. M.Soewandhie Kota Surabaya", Jurnal Kebijakan dan Manajemen Publik, Volume 4, Nomor 2, MeiAgustus 2016.

Nasution, Nur, 2004, Manajemen Jasa Terpadu (Total Service Management), Ghalia Indnesia, Bogor

Novrialdi. J,"Pelayanan Kesehatan Bagi Pasien BPJS (Badan Penyelenggara Jaminan Sosial) Di Rumah Sakit Umum Daerah Kabupaten Siak Tahun 2016", Jurnal JOM FISIP Vol. 4 No. 2 - Oktober 2017

Prasetyo, Yudi dan Eny Kusdarini, 2016, "Implementasi Program Badan Penyelenggara Jaminan Sosial Kesehatan Di Rumah Sakit Umum Daerah Pandan Arang Kabupaten Boyolali", Jurnal Pendidikan Kewarganegaraan dan Hukum 2016, Univ. Negeri Yogyakarta 
Sinambela, Lijan Poltak, 2006, Reformasi

Pelayanan Publik, Teori, Kebijakan dan Implementasi, Bumi Aksara, Bandung 